\title{
Intellectual Property Rights and the Life Science Industries
}

\author{
Past, \\ Present \\ and \\ Future
}

2nd Edition 
This page intentionally left blank 


\title{
Intellectual Property Rights and the Life Science Industries
}

Past,

Present

and

Future

\author{
2nd Edition
}

\section{Gra h a m D u t f i e ld}

University of Leeds, UK 


\section{Published by}

World Scientific Publishing Co. Pte. Ltd.

5 Toh Tuck Link, Singapore 596224

USA office: 27 Warren Street, Suite 401-402, Hackensack, NJ 07601

UK office: 57 Shelton Street, Covent Garden, London WC2H 9HE

\section{British Library Cataloguing-in-Publication Data}

A catalogue record for this book is available from the British Library.

\section{INTELlECTUAL PROPERTY RIGHTS AND THE LIFE SCIENCE INDUSTRIES Past, Present and Future (2nd Edition)}

Copyright @ 2009 by World Scientific Publishing Co. Pte. Ltd.

All rights reserved. This book, or parts thereof, may not be reproduced in any form or by any means, electronic or mechanical, including photocopying, recording or any information storage and retrieval system now known or to be invented, without written permission from the Publisher.

For photocopying of material in this volume, please pay a copying fee through the Copyright Clearance Center, Inc., 222 Rosewood Drive, Danvers, MA 01923, USA. In this case permission to photocopy is not required from the publisher.

ISBN-13 978-981-283-227-6

ISBN-10 981-283-227-0

Typeset by Stallion Press

Email: enquiries@stallionpress.com

Printed in Singapore. 
For My Parents, Henry and Sylvia Dutfield 
This page intentionally left blank 


\section{Contents}

Figures, Tables and Illustrations

List of A cronyms

ix

$x i$

Part I: Science, Drugs, M oney and Patents

1. Introduction

2. Seven Tales of a Patent

3. The Life Sciences, Business and the Patent System

Part II: Past

4. Dyes, Drugs and Domagk

5. Making $\mathrm{H}$ ormones

6. The A ntibiotics

Part III: Present

7. Big Pharma, Small Biotech

Plate Section

8. 'N o Patents on Life!'

9. M r Pharma G oes to $G$ eneva

10. The Story So Far

11. W ould W e H ave G ot W here W e A re Today W ithout Patents?

Part IV: Future

12. The Future of Patents and the Life Science Industries 
viii Intellectual Property Rights and the Life Science Industries

Bibliography 363

N ame Index 397

$\begin{array}{ll}\text { Subject Index } & 401\end{array}$ 


\section{Figures, Tables and Illustrations}

Figure 3.1 Science, business and patents - a co-evolutionary relationship

Table 4.1 Comparison of the number of completed English 78 patents for coal tar products taken during 1886-1900, by six largest English and six largest G erman firms

Table 7.1 Scientific breakthroughs in molecular biology and biotechnology

Table 7.2 Early commercial breakthroughs in biotechnology

Table 7.3 M ajor integrated life science corporations in 1998

Table 7.4 M ergers and acquisitions in pharmaceuticals, 1989-2006

Table 8.1 'Patenting life' - milestones in biotechnology patent protection

Table 10.1 Top 20 pharmaceutical companies by sales and global market share, 2007

Plate 7.1 A spirin crystals

C redit: A nnie C avanagh. C ourtesy W ellcome Library, London (ref. B 0006216)

Plate 7.2 'The German chemical octopus'. Burroughs Wellcome advertisement in The Lancet, 1918 C ourtesy W ellcome Library, London (ref. L0017863)

Plate 7.3 Frederick Banting with laboratory dog $C$ redit: W ellcome Library, London (ref. V 0025994ER) 
Plate 7.4 W ellcome Insulin, advertisement, 1929

C ourtesy W ellcome Library, London (ref. L0035388)

Plate 7.5 Penicillium mould and spores

Credit: David G regory and Debbie $M$ arshall. Courtesy W ellcome Library, London (ref. B 0004843)

Plate 7.6 Pencil sketch of the DNA double helix by Francis Crick, 1953

C redit: W ellcome Photo Library. C ourtesy W ell come Library, London (ref. B0004367)

Plate 7.7 Karl Link poses with samples of warfarin rodenticides C ourtesy $U$ niversity of $W$ isconsin-M adison A rchives (ref. X251416)

Plate 7.8 H uman blastocyst revealing the inner cell mass, source of embryonic stem cells

C redit: Yorgos $\mathrm{N}$ ikas. C ourtesy W ell come Library, London (ref. B0003312) 


\section{List of Acronyms}

A IPPI A ssociation Internationale pour le Protection de la

Propriété Industrielle (International A ssociation for the Protection of Industrial Property)

A SA A cetylsalicylic acid

CA FC C ourt of A ppeals for the Federal C ircuit

CBD Convention on Biological Diversity

CDNA Complementary (or copy) DNA

CGRFA Commission on $G$ enetic Resources for Food and

A griculture of the FA $O$

COP Conference of the Parties to the Convention on Biological

Diversity

CRC Cancer Research Campaign

DNA Deoxyribonucleic acid

EFPIA European Federation of Pharmaceutical Industries and A ssociations

EPC European Patent Convention

EPO European Patent O ffice, also Erythropoietin

ESTs Expressed sequence tags

FA $O \quad$ Food and A griculture O rganization of the $U$ nited $N$ ations

FDA Food and Drug A dministration

FICPI Fédération Internationale des C onseils en Propriété Industrielle (International Federation of Industrial Property A ttorneys)

GATT General A greement on Tariffs and Trade

GPIA Generic Pharmaceutical Industrial A ssociation

hES Human embryonic stem (cell)

ICR Institute of $C$ ancer R esearch 
IG C Intergovernmental Committee on Intellectual Property and $\mathrm{G}$ enetic R esources, Traditional Knowledge and Folklore ( of W IPO)

IP Intellectual property

IPO Initial public offering

ITC International Trade Commission

IU CN International U nion for the $\mathrm{C}$ onservation of $\mathrm{N}$ ature and $\mathrm{N}$ atural Resources

JPO Japan Patent Office

$\mathrm{MAb} \quad$ Monoclonal antibody

MRC Medical Research Council

NBE N ew biological entity

NCE New chemical entity

$\mathrm{NCl} \quad \mathrm{N}$ ational Cancer Institute

NGO Non-governmental organization

NHS National Health Service

$\mathrm{NIH} \quad \mathrm{N}$ ational Institutes of $\mathrm{H}$ ealth

NRDC N National Research Development Corporation

NSA ID Non-steroidal anti-inflammatory drug

PAS Para-amino salicylic acid

PCR Polymerase chain reaction

PhRMA Pharmaceutical Research and M anufacturers of A merica

PLT

PMA Pharmaceutical M anufacturers A ssociation (former name of PhRM A )

rDNA Recombinant DNA

RNA Ribonucleic acid

SCP Standing Committee on the Law of Patents ( of W IPO)

SPC Supplementary protection certificate

SPLT Substantive Patent Law Treaty

TBA Technical Board of A ppeal (of the European Patent Office)

TRIPS A greement on Trade-related A spects of Intellectual

Property Rights

UNCTA D U nited N ations C onference on Trade and Development 
U POV U nion Internationale pour la Protection des 0 btentions V égétales (International U nion for the Protection of $\mathrm{N} \mathrm{ew}$ Varieties of Plants)

U SPT O U nited States Patent and Trademark O ffice

USTR O ffice of the U nited States Trade Representative

WA RF W isconsin A lumni Research Foundation

W HO World Health O rganization

W IPO World Intellectual Property O rganization

W TO World Trade O rganization

\section{Note}

In this book, branded drugs are named with the initial letter capitalised. In the case of unbranded generics, the names are entirely lower case. This may cause occasional confusion. For example, in some jurisdications 'Aspirin' is still protected as a trade mark, whereas elsewhere 'aspirin' is a generic word that anybody can use in commerce. With respect to trade marks, we follow European and British practice of spelling it as two words except when the text is on the United States, where 'trade mark' is 'trademark' (as it also is in the TRIPS Agreement). On the other hand, I eschew the nowadays common practice of using the 'TM' symbol (except in direct quotes) since, like unnecessary road signage, it is a form of visual clutter and is best reserved for marketing literature. 
There needs no verse to beavtifie thy praise Or keepe in memory thy spotless name Religion, vertve, $\&$ thy skil did raise A threefold pillar to thy lasting fame Though poisnvs envye ever sovght to blame, Or hyde the frvits of thy intention Yet shall all they commend that high desygne of purest gold to make a medicine That feele thy helpe by that thy pure invention

This is a tribute to one Francis A nthony Doctor in Physick carved on a stone in the N orth A isle of the Priory Church of St Bartholomew the $G$ reat at Smithfield, London. C oincidentally, his year of death, 1623, saw the passage of one of the first ever patent laws, the Statute of M onopolies. 